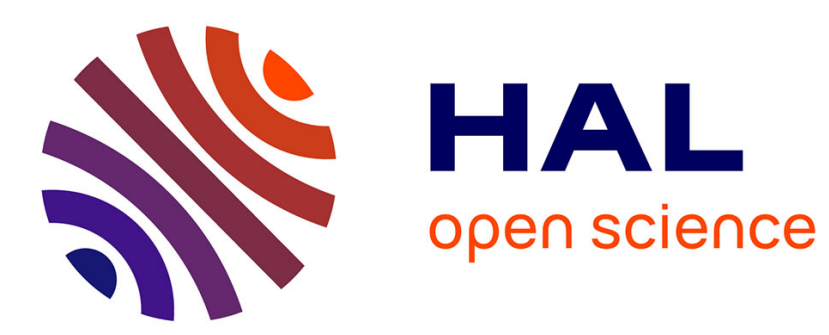

\title{
Macpherson Country: genealogical identities, spatial histories and the Scottish diasporic clanscape Paul Basu
}

\section{To cite this version:}

Paul Basu. Macpherson Country: genealogical identities, spatial histories and the Scottish diasporic clanscape. cultural geographies, 2005, 12 (2), pp.123-150. 10.1191/1474474005eu324oa . hal00572148

\section{HAL Id: hal-00572148 \\ https://hal.science/hal-00572148}

Submitted on 1 Mar 2011

HAL is a multi-disciplinary open access archive for the deposit and dissemination of scientific research documents, whether they are published or not. The documents may come from teaching and research institutions in France or abroad, or from public or private research centers.
L'archive ouverte pluridisciplinaire HAL, est destinée au dépôt et à la diffusion de documents scientifiques de niveau recherche, publiés ou non, émanant des établissements d'enseignement et de recherche français ou étrangers, des laboratoires publics ou privés. 


\title{
Macpherson Country:
}

\section{genealogical identities, spatial histories and the Scottish}

\section{diasporic clanscape}

\author{
Paul Basu
}

Department of Anthropology, University of Sussex

This paper explores the intertwining of personal or autobiographical narratives with broader cultural and historical narratives associated with particular regions, nations and diasporas. More particularly, it is concerned with the intertwining of surnames, place names and 'place-stories', and with notions of clanship, clanlore and clanlands, as resources used in the negotiation of self-identity among members of the transnational Scottish heritage community. Using the spatial histories and mnemonic practices of the Clan Macpherson as examples, it demonstrates how the 'romantic ideology' of Highland clanship serves to re-root members of an 'unsettled' settler society in what is perceived as their ancestral homeland. This (re-)establishment of kinship ties to a particular territory is effected through various enunciative acts: for instance, becoming acquainted with the clan's origin myths, slogans, stories and symbols; visiting the clanlands and those collective 'sites of memory' associated with events in clan history; participating in clan marches and ceremonials; and tracing the family tree. Whilst this 'sedentary poetics' of Highland clanship entails a re-essentialization of identity that has become morally untenable in the contemporary West, it is argued that, in the context of Scottish diasporic roots-tourism, the assertion of a close bond between blood and soil is more benign. For those who, by virtue of a particular surname, or through the labours of their genealogical research, have identified themselves as members of a Scottish Highland diaspora, the ideal of Highland clanship provides a powerful 'answering image' to that represented by the indigenous peoples and cultures of the countries in which their migrant ancestors settled. Sensing their own (vicarious) complicity in the violences of colonization and thus questioning the legitimacy of their right to belong in lands historically appropriated from indigenous populations, the clan provides its diasporic members with the possibility of recovering their own indigenous identity.

ColleEn. My grandfather was a wonderful storyteller and he told us a lot of stories about this area and it wasn't until I started looking into who the Macphersons really were that I realized these stories were Macpherson heritage stories ... Like Cluny Macpherson and the cave ... Cluny Macpherson dressing in servants' clothes to escape the English ... a lot of that kind of story ...

SHEILA. He'd obviously been brought up on that ... he probably got them from his father.

ColleEn. But walking around here ... it just felt ... ah! 
SHEILA. To think that, you know, we could belong here ...

ColleEn. We do belong here ... this place is part of our heritage. And, for me, it's the mystery of, well, this old tree here ... maybe my great-grandfather walked past it. It's much, much more than knowing who they were - it's a sense of, well, they walked here, they worked here, they were born here ... they were married and died here.

SHEILA. South Africa's a very new country, you know. It's got no history really, no real history like we've got over here.

(Badenoch, Inverness-shire, Scotland, June 2000)

A

$s$ with many such conversations recorded in the course of two year's fieldwork journeying with 'roots-tourists' in the Scottish Highlands and Islands, into this exchange between a mother (Sheila, aged 80) and her daughter (Colleen, aged 50) is condensed a complex commentary on the problematic nature of belonging in the contemporary world. Or, perhaps one should qualify, it condenses a commentary on a certain kind of belonging for a certain kind of people - largely white, middle-class, middle-aged, educated women and men who, despite being dispersed across the globe, identify strongly with their Scottish heritage. ${ }^{1}$ In many respects, Sheila's and Colleen's (Macpherson) migrants' tales are typical: a great-grandfather who 'went missing' en route between Scotland and Australia, a later nineteenth-century emigration to South Africa where other family members had already settled, a subsequent onward migration to Canada where the family now live and where Colleen has raised her own children. Not untypical, either, is the lingering colonialist worldview sometimes still espoused by older members of such diasporas of empire: South Africa, a country without history? ... not 'like we've got over here'.

My purpose in this article is not, however, to chart the history of such colonial migrations nor to reiterate a familiar critique of colonialist ideologies, but rather to consider the influence of these discourses on the emergence and performance of a Scottish diasporic consciousness. As such, I am less concerned with the violences associated with the colonial settlement of the 'new world' per se (including the violence of constructing that world as 'new' and without history) than with exploring a particular response to a crisis in belonging that has been characterized as a post-colonial unsettling of settler societies. ${ }^{2}$ As Ann Curthoys observes in the context of the rising prominence of the Aboriginal rights movement in Australia, many of those white Australians who trace their roots to Britain's 'Celtic fringe' hitherto harboured a conviction that their migrant forebears were not the colonizers, but the colonized: the victims rather than the perpetrators of displacement, exiles forcibly expelled from their respective old countries. Now, Curthoys suggests, forced into questioning the legitimacy of their claims on the supposed 'empty lands' in which their uprooted ancestors settled, they are in danger of suffering a second (symbolic) expulsion, becoming 'morally dispossessed ... ethically homeless'. ${ }^{3}$

Invoking an (idealized) Aboriginal intertwining of ancestral presence, spiritual power and totemic landscape, the Australian historian Manning Clark similarly exhorts: 
We white people are condemned to live in a country where we have no ancestral spirits. The conqueror has become the eternal outsider, the eternal alien. We must either become assimilated or live the empty life of a people exiled from their source of spiritual strength. ${ }^{4}$

Whilst Clark characterizes the two options available to the descendants of the settlercolonists as either eternal exile or assimilation to an Aboriginal Australia, a third response is also possible: one in which white Australians turn to their own ancestral lands and stories to find some 'answering image' to that represented by traditional Aboriginal culture. ${ }^{5}$ Born from an uneasy awareness of the contingencies of identity and the impermanence of its relationship with place, this answering image may manifest itself in a quest to 'rediscover' what is perceived as a lost, rooted, genealogical identity: a journey which often begins with cataloguing the births, marriages and deaths of a family history, but which often culminates in a 'return' to that far country from which the ancestors came.

Such practices are not, of course, evident only among the descendants of Scottish settlers in Australia or elsewhere in the Scottish diaspora; but the diasporic Scots do have a particularly resonant resource to draw upon in the construction of their own 'indigenous' identity: the notion of the Highland clan. ${ }^{6}$ My objective here, then, is to examine the articulation of what Paul Gilroy terms the 'sedentary poetics' of blood and soil in the context of Scottish diasporic heritage-tourism, ${ }^{7}$ and, more particularly, to explore how this poetics is articulated through intertwining ideas of clanship, clan lore and clan lands (kinship, narrative and place): how these ideas serve to re-root an existentially homeless people in a landscape other than that in which they live their day-to-day lives. In so doing, my intention is not to valorize this 'essentialization' of identity, but rather to engage with Stuart Hall's caveat that, in pursuing a critique of such constructions, "we should not, for a moment, underestimate or neglect the importance of the act of imaginative rediscovery which this conception of a rediscovered, essential identity entails' ${ }^{8}$ My anthropological project is therefore not to debunk a myth that many of my informants ostensibly live by, but to take seriously the myth as myth. Such a strategy enables us to perceive the performative nature of these practices: indeed, to understand how, through various 'enunciative' acts such as pursuing genealogical research, attending clan gatherings, learning clan stories and walking clan territories, both genealogical/clan identities and the homelands/clanlands in which they are rooted are brought into being. ${ }^{\text {? }}$

These performances of extremely localized identities entail not only a poetics but also a politics, and it is well to remember that this same conflation of blood and soil continues to fuel ethnic conflict throughout the world. The politics with which I am concerned is of a different order, however, insofar as it appeals to a more benign sense of territorial belonging which is divorced from the very real politics of landownership in the contemporary Scottish Highlands. It may be argued that this desire to root oneself in an imagined ancestral homeland - 'a place', in the words of one informant, 'of unproblematic belonging' - represents, as Gilroy contends, 'a turning away, a retreat inwards, from the difficult political and moral questions which the issue of identity poses'. ${ }^{10}$ The retreat from the imagined complexities of 'diaspora' to the imagined certainties of 'homeland' should not be dismissed, however, and, even in the relatively 
'depoliticized' realms of heritage-tourism, we need to understand just how 'stasis and purity are asserted ... against historical forces of movement and contamination' - as creative acts as well as violent ones, as James Clifford maintains. ${ }^{11}$

What I hope to illuminate in this paper is how, in their negotiation of this politics of identity, members of the transnational Scottish heritage community are able to draw upon the 'sedentary poetics' of Highland clanship to assert 'stasis and purity' not only against historical forces of movement and contamination but also co-existently with them. My aim is therefore to explore the ways in which members of an 'unsettled' settler society succeed in re-rooting themselves in - and re-routing themselves to what they regard as their ancestral homeland. Utilizing the fruits of their family history research, this entails the creative intertwining of autobiographical and genealogical narratives with broader cultural and historical narratives associated with particular regions of Scotland: an intertwining of family surnames, place names and 'place-stories' with notions of Highland clanship, clan lands and clan lore, which may be understood as 'creative' insofar as they are also generative of the relationships and continuities they assert.

The paper is divided into three main sections: the first, 'Surveying the Highland clanscape', provides an overview of what I term the 'romantic ideology' of Highland clanship in the Scottish Highlands and its diaspora. In the second section, 'Macpherson Country', I turn from the general to the particular and explore how this ideology is mapped on to the contemporary Highland landscape using the traditional lands and lore of the Clan Macpherson in Badenoch, Inverness-shire, as a case example. After making a journey through the topographie légendaire of the Clan Macpherson, I demonstrate how the clan and its place-stories are effectively, and affectingly, 'represenced' in the Badenoch landscape through the activities of the Clan Macpherson Association and its international membership. In the third section, 'Living in a new (Macpherson) Country', I draw upon the work of the Melbourne-based historian Paul Carter and chart something of the 'spatial history' of the Macpherson diaspora in Australia, following not only the migration of Macpherson settlers but also Macpherson place names (including surnames which become place names). I conclude by attempting to make more explicit some of the broader implications of the preceeding discussions and their contribution to a cultural geography of identity in the contemporary world. ${ }^{12}$

\section{Surveying the Highland clanscape}

The Gaelic word clann literally translates as 'children', 'offspring' or 'descendents', ${ }^{13}$ but Highland clanship not only evokes a sense of belonging to an extended family with a common ancestor (a people 'of one blood'); it also implies a marriage between that common blood and the territory it has historically occupied. ${ }^{14}$ The 'golden age' of clanship is generally bracketed between $c .1500$ and 1746 (ending abruptly, so the myth goes, on the battlefield of Culloden). In fact the system was already well in decline by the end of the seventeenth century, ${ }^{15}$ and we should therefore treat with caution 
Samuel Johnson's classic account of the 1770s, in which he portrays clanship as an archaic, tribal survival:

The inhabitants of mountains form distinct races, and are careful to preserve their genealogies. Men in a small district necessarily mingle blood by intermarriages, and combine at last into one family, with a common interest in the honour and disgrace of every individual. Then begins that union of affections, and cooperation of endeavours, that constitute a clan. They who consider themselves as ennobled by their family, will think highly of their progenitors, and they who through successive generations live always together in the same place, will preserve local stories and hereditary prejudices. Thus every Highlander can talk of his ancestors, and recount the outrages which they suffered from the wicked inhabitants of the next valley. ${ }^{16}$

Such a view of territorial stability and close blood-ties has been challenged by more recent commentators and characterized as part of the romanticization of the Highlands associated with Sir Walter Scott. Lynch, for example, argues that,

The nineteenth- and twentieth-century cult of the Highlands - of clan tartans, clan maps and clan societies - have all tended to obscure what a clan was. Few clans had a compact block of territory, either in the medieval period or later; 'clan maps' at best indicate where surnames occurred, but not a clan territory. ... In most cases, kinship and a common surname obtained only to the inner circle of the chief's family or to cadet branches of it. The notion that all members of a clan were descended from a common and distant ancestor is a nonsense. ... Clan society was fluid and eclectic. ${ }^{17}$

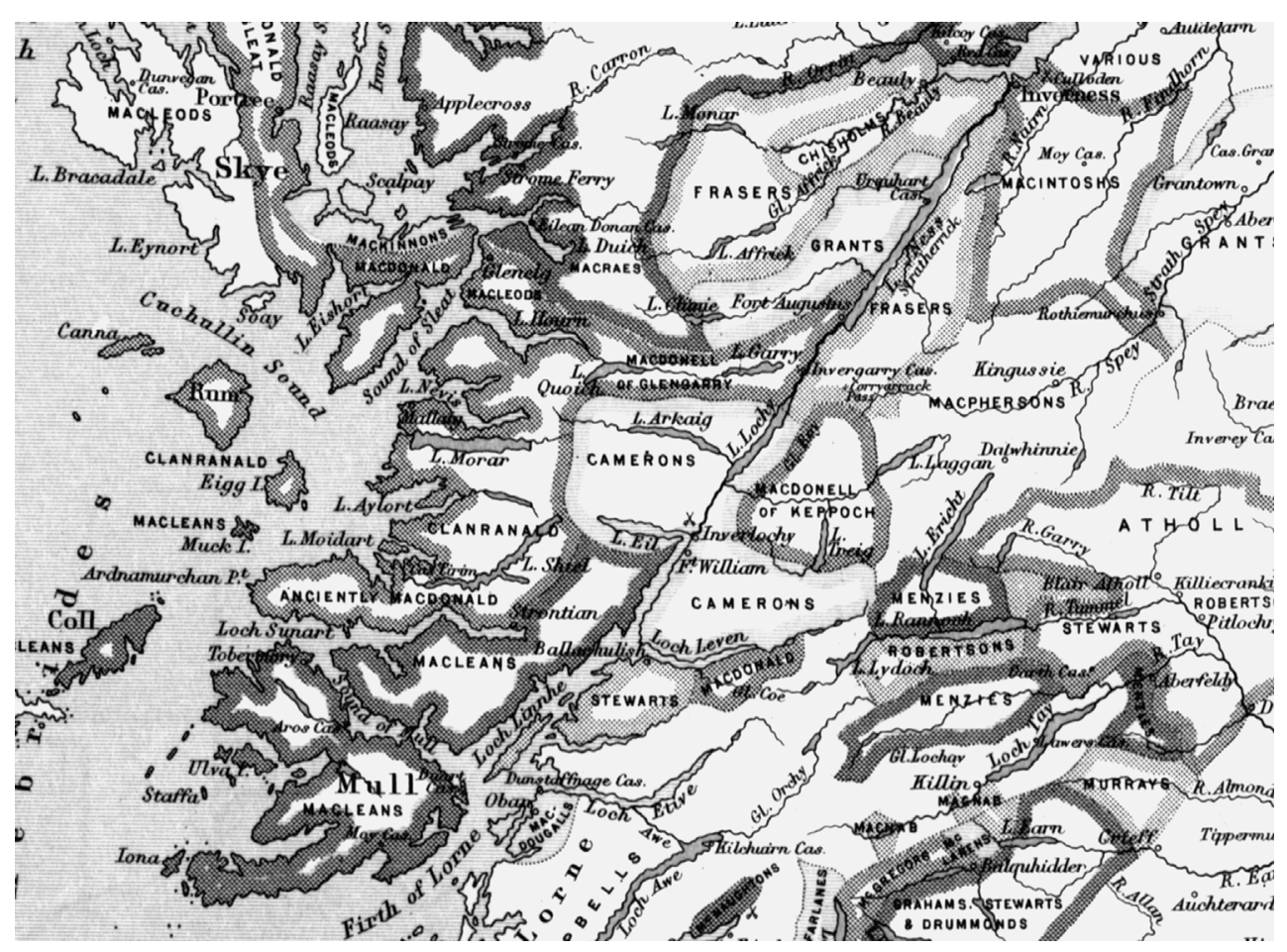

FIGURE 1 Detail of a 'clan map', identities inscribed onto the landscape. (Edinburgh Geographical Institute.) 
Drawing on more ethnographically informed analyses of kinship systems, Dodgshon stresses that the Highland clans should be understood not as literal descent groups, sustained 'by inertia or conservativism', but rather as 'changing, responsive institutions' able to adapt to unfolding sociopolitical and economic conditions. He notes that such hybrid systems of alliance must, however, lean more heavily on an ideology of kinship and 'on self-conscious displays of unity and self-justification' - an observation as pertinent to the understanding of modern, international clan societies as for the 'traditional' social structures Dodgshon is himself concerned with. ${ }^{18}$

In popular Highlandist discourse, academic quibbles over the historical constitution of clan society and the inventedness of its traditions are, however, largely irrelevant, since it is the 'romantic ideology' of clanship that continues to be promulgated and consumed with enthusiasm. This is particularly true in the Scottish diaspora, and especially among members of the North American Scottish heritage community, for whom affiliation to a clan society is frequently central to the practice of 'being Scottish', and who perform clan duties with a seriousness that baffles most homeland Scots. In North America, this devotion to clan is often founded on a number of erroneous assumptions: the assumption, for instance, that a shared surname is a reliable indicator of shared kinship (that every MacDonald, for example, is biologically related and descended from Donald of Islay, grandson of Somerled, progenitor of the clan). Indeed, the ostensible purpose of genealogical research for many such clansfolk is to find the 'missing link' that connects their own family histories with these chiefly lineages that emerge dimly from Scottish mytho-history. Thus many Scottish-Americans join clan societies that share their surname, and as clan has come to mean 'family', so clan history becomes their own family heritage. ${ }^{19}$

Although Dodgshon has demonstrated that powerful descent groups effectively 'grew down' into a territory through 'infiltrating the landholding hierarchy', ${ }^{20}$ the romantic ideology of clanship portrays the clan emerging autochthonically from the land. This is reflected in the celebrated notion of dùthchas, a Gaelic term that has no exact English equivalent and which can be used to refer to a person's native land, to hereditary rights of tenure to land and to more general senses of cultural heritage. Noting the marriage of clan and land evinced in 'territorial sobriquets' such as Ditthaich Mbic Aoidh (Mackay Country) and Srath Mhic Fbionghuin (Strath of MacKinnon), the Gaelic scholar Michael Newton argues that dùthchas 'ties together a sense of inheritance and territory':

One's dùthchas is one's set of hereditary qualities, one's culture, one's homeland. The adjective dùthchasach describes that which is indigenous, native and inherited, and the same word can refer to a native of some particular place. This demonstrates that place is integrated into a sense of identity and ancestry in Gaelic tradition. ${ }^{21}$

The resonance of this concept has been exploited in various heritage initiatives in the Highlands and Islands. The anthropologist Sharon Macdonald has, for instance, examined its use at the Aros visitor centre on Skye, which is also known as Dualchas an Eilein, meaning 'the heritage of the island' - where, Macdonald suggests, heritage may be understood as an uncommodifiable, 'inalienable possession' of the islanders, something that may be kept while yet being given away. ${ }^{22}$ 
The traditional integration of place, ancestry and identity represented by dùthchas is also evident in the war-cries or slogans of many clans. Such slogans, part of each clan's 'sacra', are thought to pre-date heraldic conventions and originate quite literally as rallying calls used in battle. Many refer to clan strongholds, gathering places, or prominent hills, mountains or lochs in the clan territory: places that symbolize the wider clan homeland and for which the clansmen were presumably prepared to die (Table 1). These slogans are now often called out during clan ceremonials and parades, and are sometimes employed as the titles of clan newsletters or annuals: thus the Clan Macpherson annual is entitled Creag Dhubb and that of the Clan MacRae, Sguir Uaran.

As the Scottish heritage revival has gained momentum over the past 30 years, so too has the cult of the clan, and there are now many hundreds of clan associations throughout the world, each recognizing a particular Highland lineage, and each identifying a specific region within the Highlands and Islands as its ancestral homeland. In addition to more localized gatherings within the diasporic countries, many clan societies organize regular tours to Scotland to visit these postulated clan territories and participate in international gatherings. Such gatherings generally follow a standard programme including marches through the clan territory, parades at local Highland Games, excursions to places of interest associated with the clan, formal dinners and céilidhs, lectures on clan history and genealogy, church services and, quite often, visits to Culloden battlefield. As Celeste Ray notes in her study of the Scottish heritage revival in North Carolina, the Scotland they come to visit is mapped 'not by current

TABLE 1 Examples of the use of place names in clan war-cries or slogans

\begin{tabular}{|c|c|c|}
\hline Clan & Slogan & Notes \\
\hline Buchanan & Clar Innis & Clarinch, an island in Loch Lomond \\
\hline Campbell & Cruachan & A prominent mountain by Loch Awe \\
\hline Fraser & A 'Mbor-fhaiche & 'The great field' \\
\hline Grant & Stand Fast, Craigellachie & Craigellachie is a rocky eminence in Strathspey \\
\hline MacBain & Kinchyle & Clan territory on the south side of Loch Ness \\
\hline MacDonald & Fraoch Eilean & 'The heathery isle' \\
\hline MacDonell & Creag an Fbithich & $\begin{array}{l}\text { 'The raven's rock' - the clan badge depicts a } \\
\text { raven on a rock }\end{array}$ \\
\hline MacFarlane & Loch Sloidh & Loch Sloy, Dunbarton \\
\hline MacGillivray & Dunmaghlas & Dunmaglass, the clan territory in Strathnairn \\
\hline MacGregor & Ard-choille & 'The high wood' \\
\hline MacIntyre & Cruachan & $\begin{array}{l}\text { As Campbell, indicating allegiance to feudal } \\
\text { superiors }\end{array}$ \\
\hline Mackintosh & Loch Moigh & Loch Moy, Strathdearn \\
\hline MacLaren & Creag an Tuirc & 'The boar's rock' \\
\hline MacLennan & Druim nan deur & 'The ridge of tears' \\
\hline Macpherson & Creag Dhubb & 'The black rock', a prominent hill in Badenoch \\
\hline MacRae & Sguir Uaran & A prominent mountain in Kintail \\
\hline Morrison & Dùn Eistean & $\begin{array}{l}\text { 'Hugh's Castle', a stronghold near the Butt of } \\
\text { Lewis }\end{array}$ \\
\hline Munro & Caisteal Folais'n a Theine & $\begin{array}{l}\text { 'Castle Foulis in flames', Castle Foulis being the } \\
\text { seat of the clan chief }\end{array}$ \\
\hline Stewart & Creag an Sgairbh & 'The cormorant's rock' \\
\hline
\end{tabular}


economic or population centres, but by places of historical relevance to the[ir] heritage'. ${ }^{23}$ This 'clanscaping' of the Highlands, she argues, may be understood as 'a further evolution of the way Scottish landscapes ... have been invested with varying meanings by and for various "others": elite others, tourist others, even returned others. $^{24}$

I should like to examine this clanscaping of the Highland heritage-landscape in more detail by focusing on a particular clan - the Clan Macpherson - and its clan lore and clan lands. My interest here is to highlight the relationship between landscape, narrative and identity, and to explore how, in the process of 'learning' the clan's 'place-stories' (through the body as much as through the mind), a sense of personal identification with both clan and territory is effected in the individual.

\section{Macpherson Country}

The territory historically associated with the Clan Macpherson is the old Lordship of Badenoch in the Central Highlands, which has as its capital the town of Kingussie (Figure 2). The name Macpherson is derived from the Gaelic Mac a'Phearsain, meaning 'Son of the Parson', and, according to one account, the progenitor of the

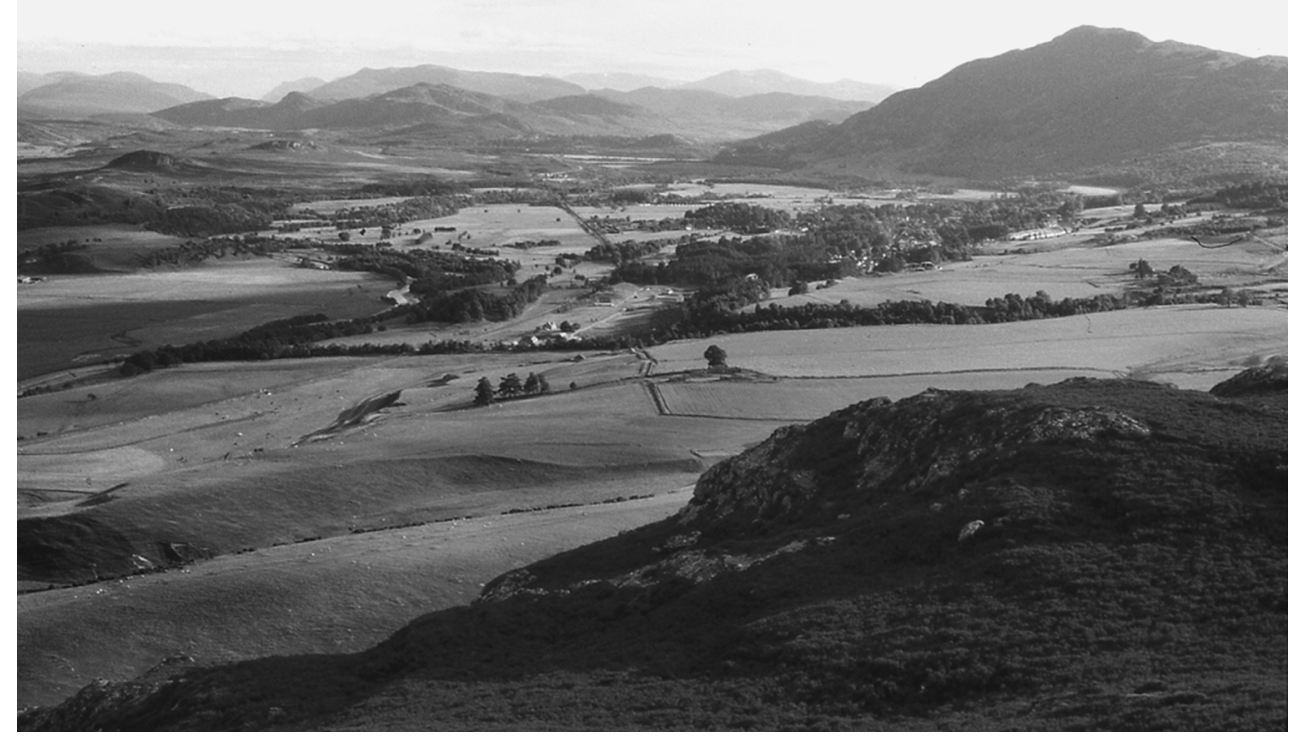

FIGURE 2 Looking west from Creag Bheag above Kingussie across Badenoch. Creag Dhubh, the totemic hill of the Clan Macpherson, rises above the town of Newtonmore in the middle distance. (Paul Basu.) 
clan was a twelfth-century prior named Muireach Catanach (hence the clan is also known as Clan Mhuirich). The Macphersons were part of a confederacy of clans known as the Old Clanchattan, which originated in the Lochaber area and migrated east across the Highlands between about 1350 and 1450, gradually disintegrating as the various branches (including Macphersons, Mackintoshes, MacMillans and MacNivens) competed for dominance. The Macphersons came to prominence in Badenoch after first ousting the hitherto powerful Comyn overlords and then displacing their own erstwhile allies, the MacNivens, who had previously settled in the region. Acquiring the clan seat, Cluny, by marriage bond, the Macphersons emerged as the new landholding elite in the area, finally gaining the dithchas - in this context, the legal 'right of ancient possession' - to the territory in $1600 .{ }^{25}$ Through the granting of lands to cadet branches of the family and through strategic marriage practices (generally speaking, males marrying exogamously, females marrying endogamously), the history of the Macphersons in Badenoch provides an excellent example of a kingroup "growing down' into a territory. ${ }^{26}$

The Clan Macpherson has thus been 'mapped' onto the Badenoch landscape, not only in the names of townships and estates associated with the various branches or sliochdan of the clan (so that one gets the Macphersons of Cluny, the chiefly line, the Macphersons of Pitmain, of Glentruim and so forth - and the heads of these families become known simply by the placenames: i.e. Cluny, the chief, Pitmain, Glentruim) but also in those sites which may be said to 'bear witness' to the clan's history and around which stories continue to be told. For instance, in the shadow of Creag Dhubh, the clan's totemic hill that stands sentinel at the heart of Macpherson Country, there is the site of the fourteenth-century Battle of Invernahavon, a conflict fought against the raiding Clan Cameron, the Macphersons' neighbours to the west. And then there is the Iron Age souterrain at Raitts near Kingussie, known locally as An Uaimb Mhòr (the Great Cave) or the MacNivens' Cave. The latter name recalls a grim story that dates to the feud between the Macphersons and MacNivens, in which a group of MacNivens used the souterrain as a hide-out but, through the cunning of Cluny's men, were discovered and promptly dispatched.

Another often-told Badenoch story is that of the infamous Captain John Macpherson, the 'Black Officer of Ballachroan', who was killed dramatically in an avalanche in 1800. The ruins of his once-impressive farmhouse, said to have been built from stones taken from Kingussie's old parish church, remain shrouded in superstition (Figure 3). As Meta Scarlett, a local writer, explains,

From my earliest childhood I heard tales, the oral tradition handed down by my great-great-grandmother who was his contemporary, in which he was represented as the incarnation of evil, the hated recruiting officer called black not for his dark colouring, but for his black heart, who tricked the local lads into enlisting in King George's army, who trafficked with the Devil and who came in the fullness of time to his inevitable doom.

He sounded like a character from a ballad or a ghost story, but he was real enough. I had only to open our sideboard to see his cream jug and sugar bowl, simple homely things bought at the Ballachroan sale in $1821 .^{27}$ 


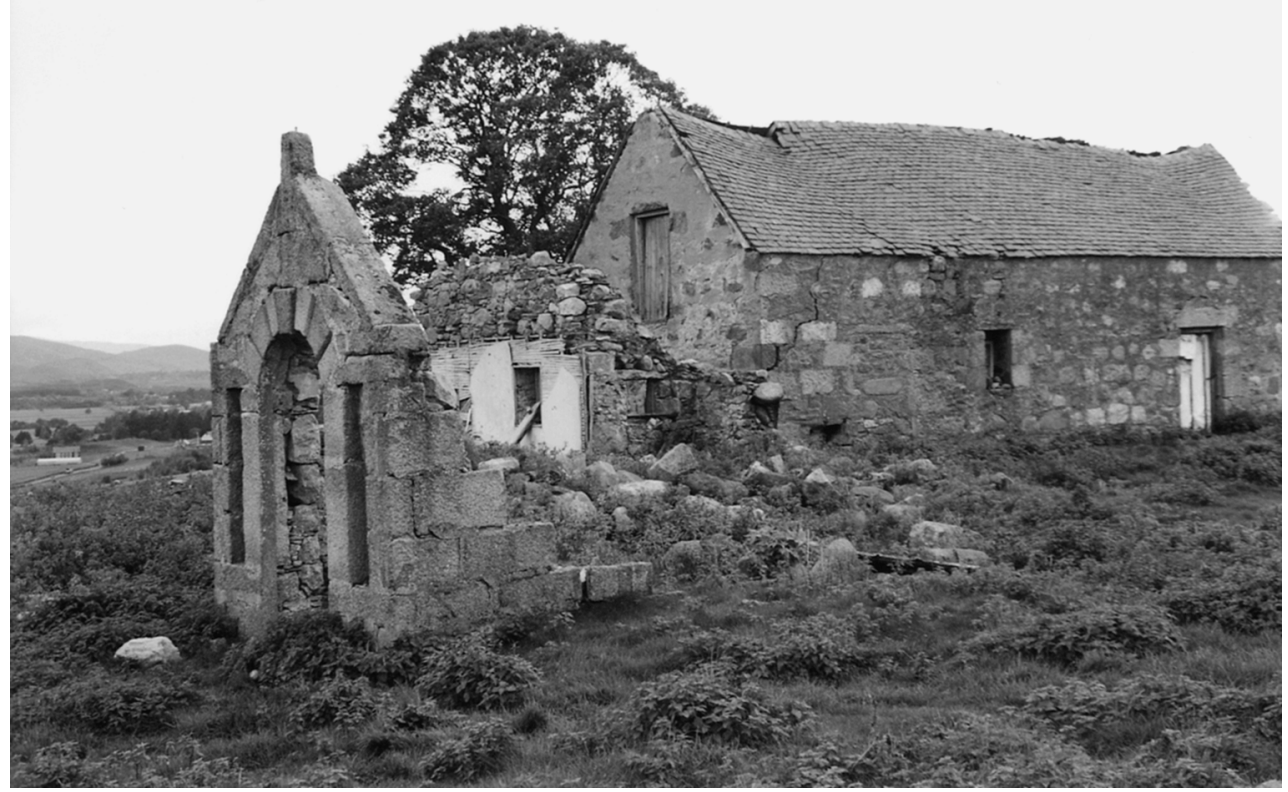

FIGURE 3 The ruins of Ballachroan, near Kingussie. (Paul Basu.)

In addition to being reviled for his deviousness in enlisting recruits and his other misdemeanours, the Black Officer was also responsible for introducing improved methods of agriculture to the area. By adding lime to the peaty soil around Ballachroan and introducing a turnip crop, the Captain prospered as a farmer, but his success was attributed to his being in league with the Devil. Indeed, even today, visiting the ruinous farmhouse occasions the telling of a tale in which the Captain successfully outwitted the Devil himself.

The Evil One agreed to give the Captain whatever he might desire and his first wish was that the lands of Ballachroan might for their fruitfulness be a wonder to all who saw them. To this Satan agreed provided he would get half the crop. That year Captain Macpherson sowed a grain crop as usual, reaped in a wonderful harvest and when the Devil came to claim his due offered him the roots. Satan protested and was told that the following year he would get the crop and the Captain would keep the roots. Next spring Macpherson planted only potatoes and turnips which gave a marvellous yield and when the time came to fulfil his bargain he gladly surrendered the 'shaws.' ${ }^{28}$

Needless to say, Macpherson of Ballachroan's death at the Gaick avalanche catastrophe on 'Yule Eve 1800' was seen by many as the Devil's retribution, and it too features prominently in local folklore, gruesomely elaborated in every telling. The site where Macpherson's body was found is marked by a cairn on which the last poignant stanza of an elegy by a contemporary bard, Duncan 'Smith' MacKay, is inscribed: 
O duisgibh-se mu 'm fas sibh liath, 'S dluithibb bhur cas risant-sliabb Feuch gu 'm bi bhur fasgadh deant $M u$ ' $n$ teid a' ghrian a laidhe oirbhe.
Oh waken before you grow grey,

Quicken your foot towards the moor,

See that your shelter is made

Ere the sun sets on you. ${ }^{29}$

As Keith Basso has compellingly argued with reference to the Western Apache, through the telling of narratives, places in the landscape become transformed from geographical sites into 'something resembling a theater, a natural stage upon the land ... where significant moral dramas unfolded in the past'. ${ }^{30}$ Such Macpherson place-stories demonstrate vividly how 'wisdom' comes to 'sit' in the Scottish Highland landscape too.

Perhaps the most significant of the modern 'moral dramas' to have unfolded across the Highland landscape is that of the Jacobite Rebellions - particularly the Rebellion of 1745-46. A drama shot through with motifs of love, loyalty, exile and loss, the story of 'the Forty-five' is recalled not only in those iconic sites such as Glenfinnan, where Charles Edward Stuart ('Bonnie Prince Charlie') first raised his standard, or Culloden, where the Jacobite army was finally routed by government forces, but also in countless other less prominent sites connected with 'that arduous and unfortunate enterprise'. ${ }^{31}$ Most prolific of these are those sites associated with the flight of the defeated Bonnie Prince Charlie and his supporters after the battle of Culloden, and, indeed, there is no shortage of these in Macpherson Country (the Macphersons were staunch supporters of the Rebellion). It was at Ruthven barracks, for example, across the River Spey from Kingussie, that the Jacobite armies regrouped after Culloden, fully expecting to renew hostilities until the message came from the Bonnie Prince advising them that the cause was lost and that every man should 'seek his own safety in the best way he can'. ${ }^{32}$ As the government forces launched a massive manhunt across the Highlands, the Jacobite rebels fled to the hills and hid until passage could be secured to carry them to safety in France. The tales of their adventures and exploits in hiding constitute one of the great bodies of Highland folklore and song, later to be appropriated in the Hanoverian romanticization of the Highlands and published in collections such as James Hogg's Jacobite relics. ${ }^{33}$

Every Jacobite clan has its Jacobite hero, and the Macphersons' hero is its chief of the time, Ewan or Cluny 'of the ' 45 '. In the aftermath of the Rebellion, those chiefs who would not swear allegiance to the Hanoverian crown remained outlaws and had their estates confiscated: Cluny's was among them. Thus Badenoch effectively became an occupied territory with upwards of 1000 government troops stationed on the banks of the Spey at Sherramore, Cluny Castle fired, and a bounty of 1000 guineas placed on Cluny's head. Cluny spent a remarkable nine years in hiding in Badenoch before fleeing to exile, and many of the places in which he reputedly hid may still be visited and form key sites in the Macpherson clanscape (Figure 4). The two most famous of these hideouts are Uamb Chluanaidh (Cluny's Cave) on Creag Dhubh and 'Cluny's Cage' on Ben Alder. Cluny's Cage is especially famous since it was here that the chief sheltered Bonnie Prince Charlie for six days while he awaited news of a vessel to take him to France. The Cage is also the setting of a muchcelebrated chapter in Robert Louis Stevenson's 1886 novel Kidnapped, demonstrating 


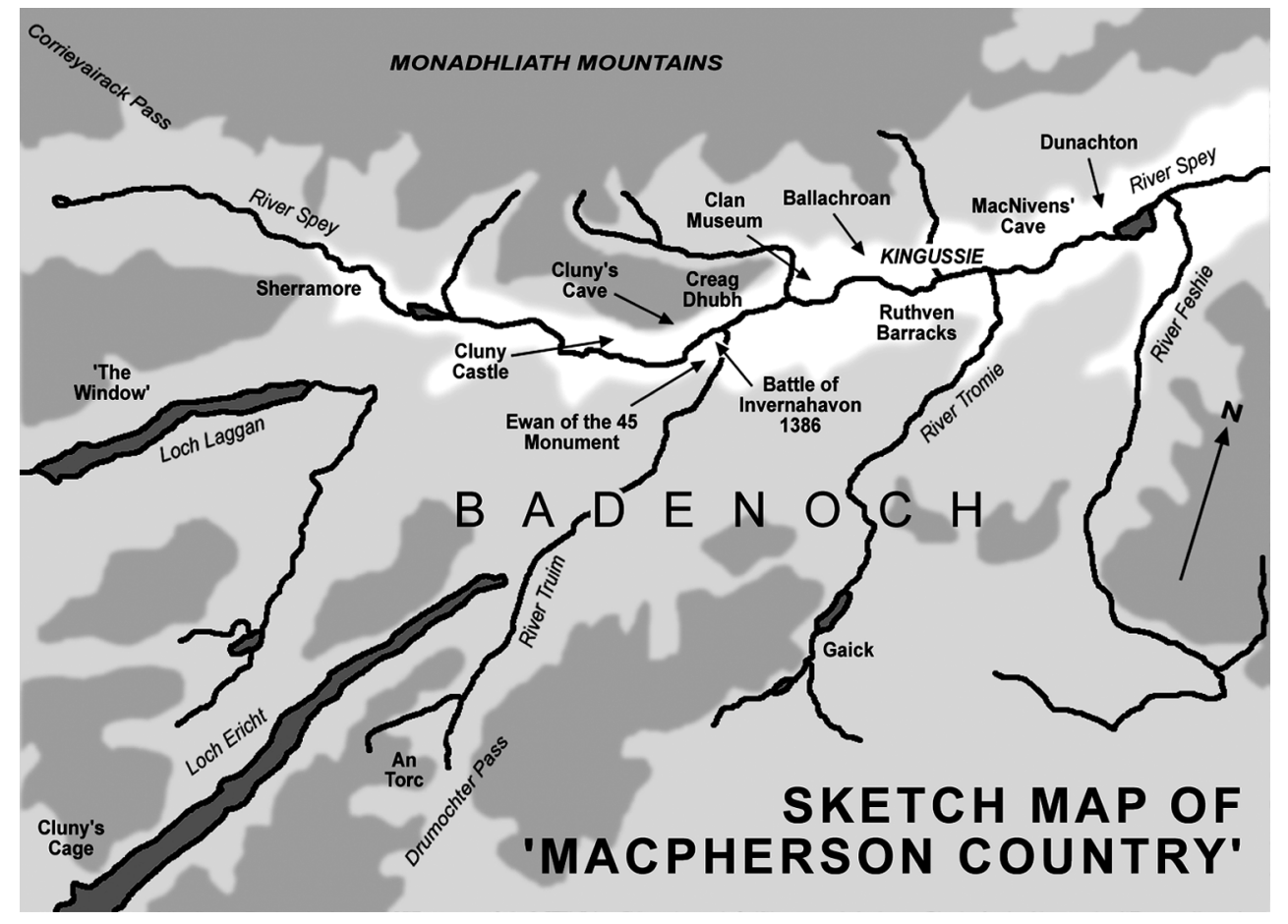

FIGURE 4 Sketch map of Macpherson Country. (Paul Basu.)

how tales of Jacobite derring-do remained popular throughout the nineteenth century. ${ }^{34}$ It was not until 1755 that Ewan himself finally escaped to France; he died there in 1764 and was buried at a Carmelite Monastery near Dunkerque, the exact whereabouts of which is now unknown. The Macphersons were eventually restored to Cluny in 1784 and Ewan's son had the family castle rebuilt. After the long, charismatic 'reign' of Ewan's grandson, however, the fortunes of the family began to decline and, in 1933, the estate finally went into receivership. Writing soon after, Seton Gordon comments, 'Truly the glory of the house of Cluny Macpherson has gone on the hill wind. ${ }^{35}$

Such, then, is the topographie légendaire of the Clan Macpherson. ${ }^{36}$ I should now like to examine how these place-stories are effectively, and affectingly, 'performed' in the Badenoch landscape. Surprisingly, this role is not fulfilled by the clan's museum in Newtonmore (Figure 5). Unlike the more recently opened Clan Munro visitor centre in Ross-shire, for example, the Clan Macpherson Museum was not established explicitly to tell a story so much as to house those 'relics and memorials' of the clan that were salvaged by the nascent Clan Macpherson Association when the Cluny estate was auctioned in 1942. The Association was formally inaugurated at its first annual rally in 1947, and it officially opened its museum (the first such clan museum) at 'Clan Macpherson House' five years later. Since then, the constitution of the clan 


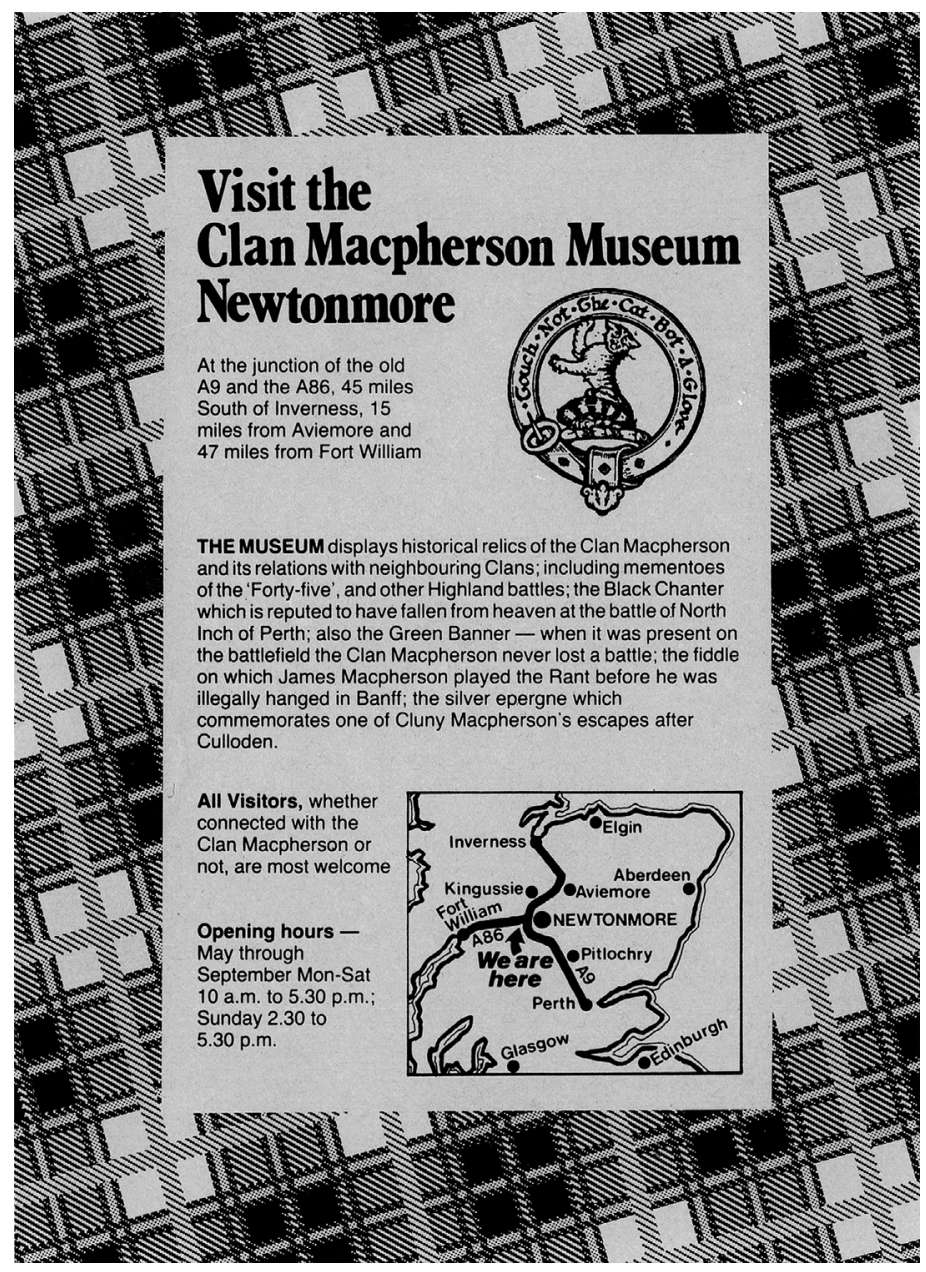

FIGURE 5 Leaflet advertising the Clan Macpherson Museum, Newtonmore. (Clan Macpherson Association.)

association has altered significantly. Thus, in the 1950 s, no more than 10 per cent of the association's members were based outside the UK; today, of the 3000 strong membership, over 60 per cent reside overseas (there are currently eight branches of the association: one each in Scotland, England, Canada, the USA, New Zealand and South Africa, and two in Australia). This reflects the more general growth in Scottish diasporic consciousness, and to a large degree has determined the function currently demanded of the museum as a 'focus' for a clan no longer acquainted with its own lands. A jumble of curios, it could be said that, whilst providing this focus for the dispersed clansfolk, the museum actually diverts their attention away from the infinitely richer mnemonic landscape outside its doors; we must therefore look elsewhere for the practice of Macpherson place-storytelling. 
We may look, for instance, to the main event of the clan association's calendar: its annual gathering in Badenoch. This rally may be understood as a 'commemorative ceremony ${ }^{37}$ or 'ritual form, ${ }^{38}$ in which the individual bodies of the clan gather together as one body in the clan's homeland. In this corporeal act of gathering, the otherwise dispersed clansfolk 'perform' their membership of the clan, assuming its heritage as their own. This performance of heritage (a laying claim to a past and a place) is perhaps most explicit in the central event of the rally, in which the clan marches from a place called Old Ralia, across the Spey bridge, to 'the Eilean', Newtonmore's sports ground, where they parade at the town's annual Highland Games (the gathering and the games are organized in tandem around the same weekend in August). The clan members are led by a pipe band, and march in full Highland dress behind the clan insignia, their chief and other senior clansfolk. The march usually draws a large crowd of spectators (locals and tourists alike), which forms a witness to the ceremony - as, indeed, does Creag Dhubh, within sight of which the event takes place (Figure 6).

After attending the Games, the clan members then make their way to the clan museum, where there is an opportunity for them to socialize more informally and enjoy a dram together. That this 'open house' takes place at 'Clan Macpherson House' is significant in itself and demonstrates that the museum acts as a substitute for the lost clan seat, Cluny Castle, where such gatherings would have traditionally taken place. But, given that the clan members here mingle not only among themselves but among

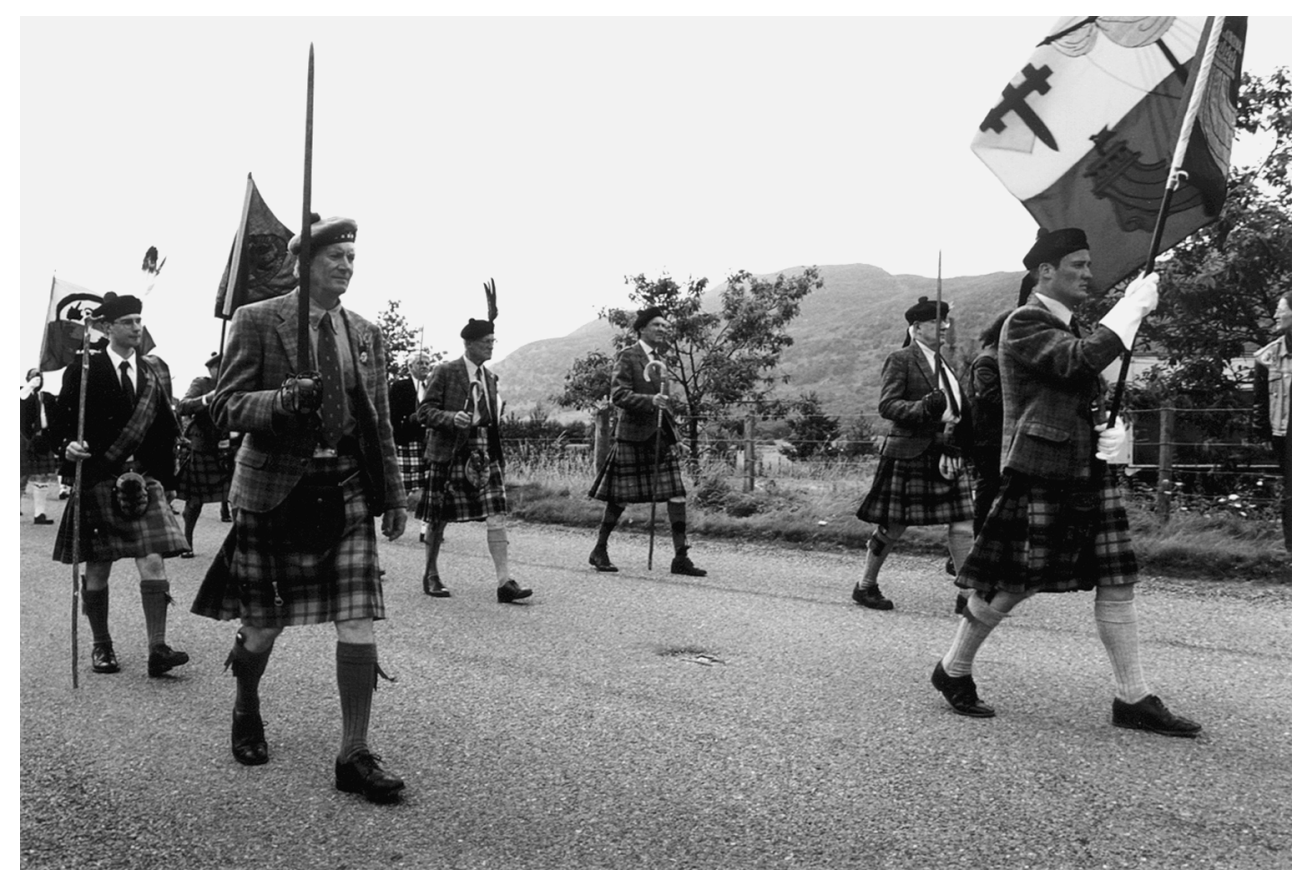

FIGURE 6 The Clan Macpherson marching to 'the Eilean', near Newtonmore, in 1999. Creag Dhubh can be seen in the background. (Paul Basu.) 
the clan's relics and memorabilia, it is also fascinating to observe how this part of the event may occasion the telling of clan stories, usually in casual conversations between more and less knowledgeable clan members as they linger over the displays. In this respect the poor labelling of objects in the museum becomes advantageous, since this provokes additional commentary and explanation. If particular interest is shown, more experienced clan members may recommend books about clan history to novices, or introduce them to other clansfolk who are recognized for their expertise on certain aspects of clan lore. Through such informal social interaction newcomers thus become increasingly acquainted with the clan's stories: to learn these stories is, in a sense, to become initiated.

Among other events, a clan walk is organized as part of each year's rally. Again, these walks are ostensibly occasions for informal social interaction, where members may enjoy each others' company as well as seeing more of the magnificent Badenoch scenery than their travels by road and rail allow (Figure 7). Beyond its sociable surface, however, these walks also constitute a form of corporeal commemorative practice through which Macpherson place-stories are 'experienced' bodily as much as cognitively. The destinations of these walks are usually places connected with Macpherson history: places that, in the words of the clan member who organizes them, have become 'totems to go and visit'. ${ }^{39}$ Recent destinations have thus included Cluny's Cave (1986), the Corrieyarrick Pass (1990), Glen Banchor (1992), Ballachroan and Gaick (1993),

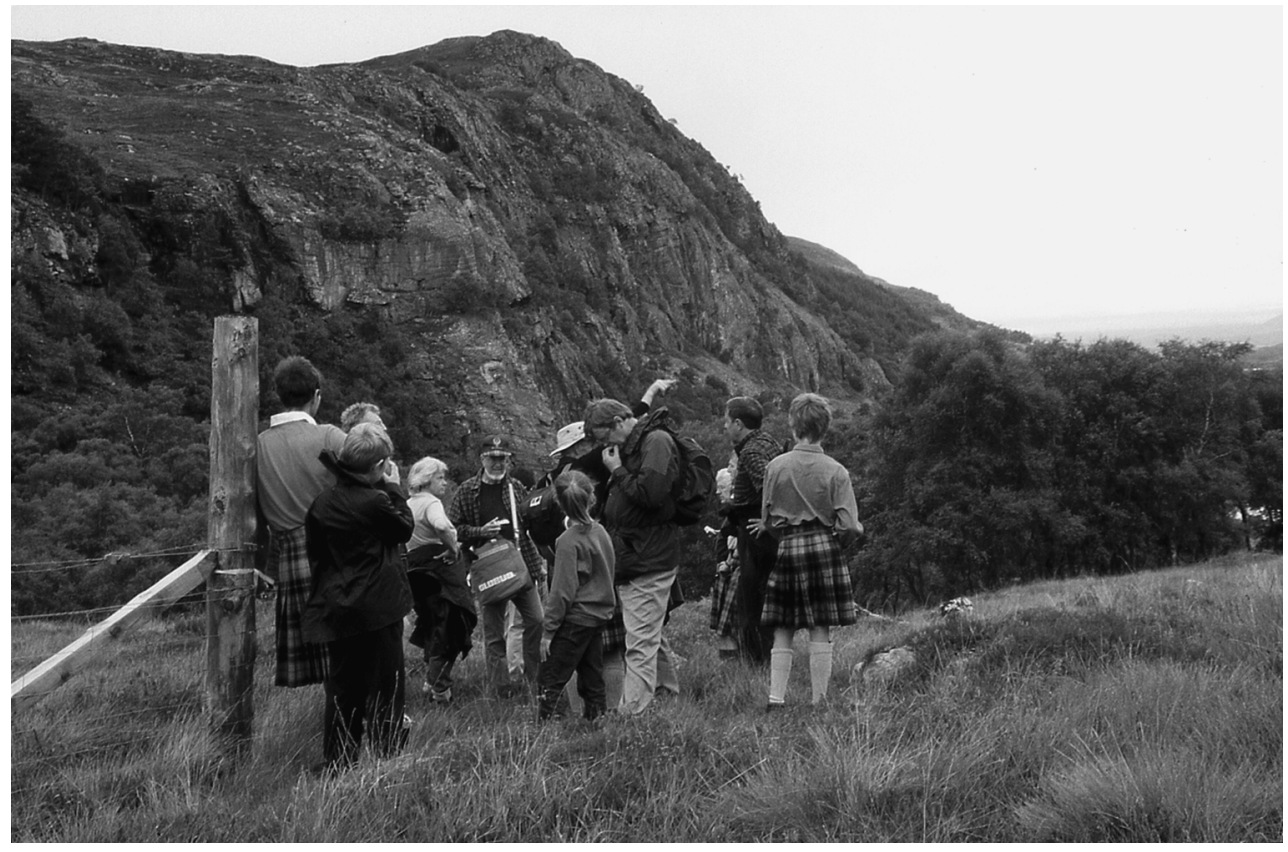

FIGURE 7 Members of the Clan Macpherson Association pausing during the clan walk in 2000. A senior member points out features in the Macpherson clanscape. (Paul Basu.) 
Cluny's Cage (1996), and Creag Dhubh (2000). Although many male participants walk dressed in their kilts of Macpherson tartan, this event is a far less 'spectacular' performance of identity than the clan march. Indeed, its performance is directed inwardly rather than outwardly, both at an individual level, through the development of a more intimate physical relationship with Macpherson Country, and at a collective level, through the shared endeavour and the conversational telling of clan stories in the very places where they happened. A 'write-up' of each walk usually appears in the following year's clan journal. In these articles, the story of the site visited and the story of the walk itself are combined, such that the 'historical' event and the 'commemorative' event become interwoven. As a commemorative practice, the walk 'remembers' the past event; in remembering the walk, the walker recalls both the past event and the event of the walk - individual heritage thus becomes closely associated with collective heritage, and the polysemic 'site of memory' becomes a site of personal identification. ${ }^{40}$

In 1996, to celebrate the 50th anniversary of the founding of the Clan Macpherson Association, it was decided that a special golden jubilee gathering would be organized. As well as staging an extra-large rally, with lots of guests and special events, it was felt that the clan should also have something more tangible to mark the occasion. The jubilee would coincide with the much anticipated 250th anniversary of the battle of Culloden, ${ }^{41}$ as well as with that period in which Ewan of the ' 45 harboured Bonnie Prince Charlie in his celebrated hideout on Ben Alder. Since there was no other memorial to their esteemed Jacobite chief, it was decided that this tangible something should take the form of a cairn erected in his honour, and that its ceremonial unveiling would be the centrepiece of the gala (Figure 8). Whilst the dedication to 'Ewan Macpherson of Cluny, Colonel of the Badenoch Men in the Forty-five' inscribed on a plaque set into the cairn makes clear its primary commemorative purpose, a closer reading of this monument reveals it to be a far more complex and fascinating 'memorial text'.

The land on which the cairn and its enclosure is located was gifted to the clan association by Euan Macpherson of Glentruim in another ceremony at the clan's 49th gathering (the year prior to the planned jubilee). This slightly elevated site, with its views across the Badenoch landscape, is key to the success of the monument, and it is worth reproducing part of Glentruim's address to the clan delivered during this ceremony to explain why:

\section{Cluny, Lady Cluny, Clansfolk -}

Welcome here today. The very last time I stood here on this piece of ground was on the 12th of January this year when Ewen, Bruce and I met here to decide whether this was the right place to build a Commemorative Cairn to Ewan of the ' 45.

The three of us stood here and we looked out there over the Upper Spey, the broad fertile valley where our ancestors lived and worked, cultivated the fields and tended their cattle. Right at the head of the valley is the ancestral home of the Head of the Clan, the House of Cluny. And over there beyond Torr na Truime where the rivers Spey and Truim join is the place where our forebears bravely fought and won the Battle of Invernahavon 600 years ago. On the cliff over there is Cluny's Cave, the place where Ewan of the ' 45 hid from the English. I like to think that on a day like today he would come out of the cave and lie down in the heather and watch the English Redcoats marching up and down in search for him in vain. 


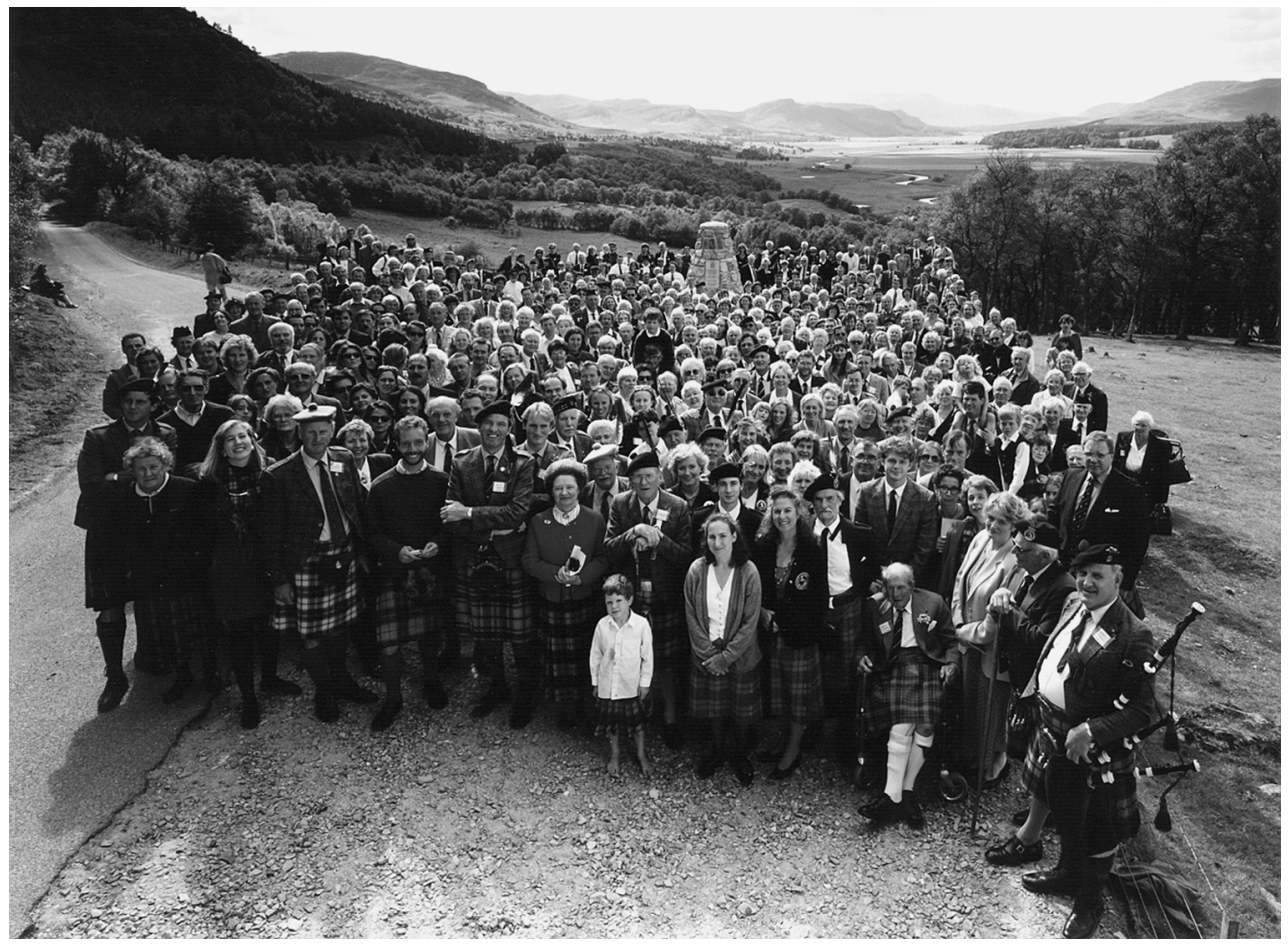

FIGURE 8482 Macphersons from 12 different countries gathered around the cairn commemorating Ewan Macpherson of the ' 45 after the unveiling ceremony, 3 August 1996. (Jerome Le Roy Lewis.)

And standing over us now, as then, is Creag Dhubh, the sentinel and guardian of our Clan through all the ages.

On that day in January this year when Ewen, Bruce and I met here it was a bitterly cold day with snow lying all around. There was not a breath of wind - utter silence. It was Ewen who suddenly turned to me and said, 'You know, if you listen very carefully you can almost hear the silence'. The three of us stood together for some moments without speaking, and listening carefully. I think that what we heard were distant echoes from all the centuries past in the long, proud history of our Clan. ${ }^{42}$

The sight of the Macpherson clanlands is thus central to the siting of the cairn - indeed, like Creag Dhubh itself, the cairn seems to be at the very centre of the territory, the point at which the echoes of the clan's place-stories are collected and focused as if through a parabolic reflector. For the uninitiated visitor to the site, these place-stories are 'gathered in' and hinted at in a compass-like dial attached to a large boulder within the cairn's enclosure (Figure 9). The particular significance of the places included on this dial is established through their very inclusion, but explication is withheld, and the visitor whose curiosity is aroused is thus encouraged to visit the clan museum to enquire. 


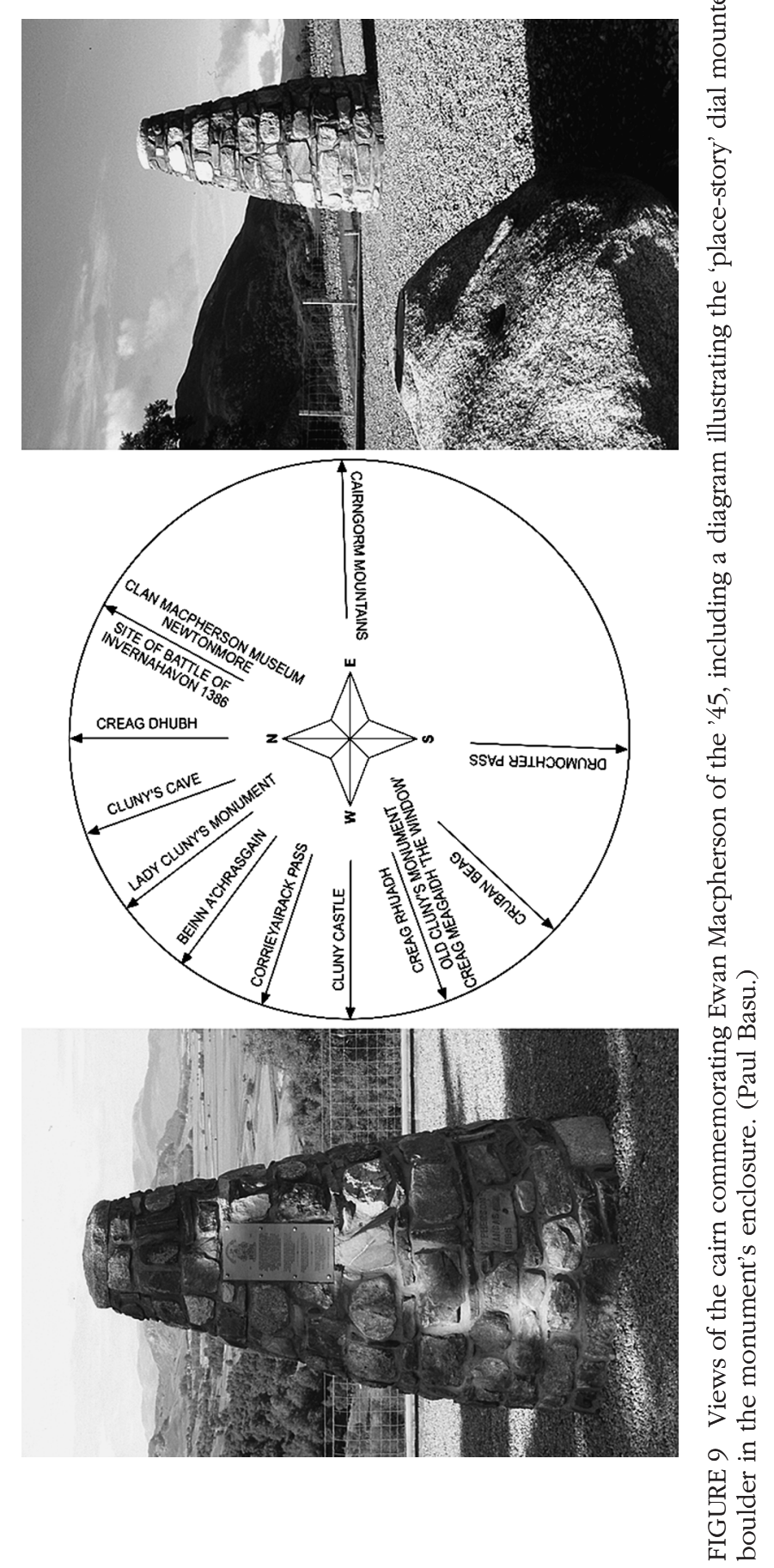

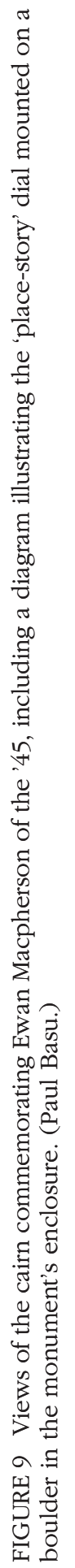


Perhaps the most remarkable aspect of the monument, however, is the fact that it is constructed from stones sent by clan members from 26 different countries throughout the world. Some of the stones are inscribed with the names or initials of those who contributed them, but the majority are anonymous within the fabric of the cairn. Records were kept, however, of every stone donated, noting the donor and details of where each stone was sourced, and these have been compiled into a commemorative 'Book of gold', which is on display at the clan museum as a memento of the jubilee gathering.

The cairn incorporates stones sourced both in the homeland and in the diaspora, literally uniting disparate fragments into one body. As Robert J. Macpherson, the architect of the memorial, explained at the unveiling ceremony, in contributing these stones, 'clansmen and women have donated a part of their country, culture and personal history'; and within the form of the cairn, the 'layers of meaning' embodied in the individual stones intricately overlap with one another. A few examples of the notes compiled in the 'Book of gold' may give some insight into the specific meanings represented in each of the stones:

- Medium size grey stone found in direct proximity of Fort Ticonderoga (French Fort Carillon), N.Y.. Still has traces of masonry on it. [The present] Cluny's direct ancestor, Allan Macpherson, was with the Black Watch at this location with Abercrombie in 1758. Given by C. Peter McPherson Fish, Keene, N.Y., USA.

- Piece of brown rock from near the bachelor officers' quarters, bldg 40 , near the north east boundary of historic Fort McPherson, Atlanta, GA, USA. Obtained by Donald and Dodie McPherson and family, Roswell, Georgia, USA.

- A large yellow coloured rectangular limestone inscribed 'McPherson Kansas 1995'. The state rock for Kansas and is found in the Flint Hills that extend in the eastern edge of McPherson County. This rock was used in the construction of a very early home in McPherson. Robert W. and Debra J. Macpherson. Robert is the Vice Chairman, McPherson Scottish Society, McPherson, Kansas, USA.

- A tiny piece of black coal and a tiny piece of red stone from McKeesport, PA, USA. Gt Grandfather MacPherson settled in the township of Elizabeth just outside of McKeesport to mine coal and the family are still in the area. The sender, Sue Anne MacPherson, of McKeesport has four sons and a daughter who are proud of their Scottish background.

- A very large, black and white stone with flakes of real gold glistening. The face is polished and has eighteen first names inscribed on it plus the first initial of seventeen other members. From the Western Deep Levels Gold Mine in South Africa, being the deepest mine in the world. Sent by Allan D. MacPherson of Rivonia, South Africa on behalf of the South African Branch of the Clan Macpherson Association.

- A small piece of brown petrified wood and polished at one end. From Mount Abundance Station, Roma, Queensland, Australia. Settled in 1847 by Allan Macpherson of Blairgowrie, Scotland. He abandoned the Station in 1856 because of droughts and attacks by Aborigines on stock and settlers. Allan was an ancestor of the present Chief. Given by Peter Keegan, Roma, Queensland, Australia.

Each stone thus represents, metonymically, its own place-story: each tells an individual family narrative, but each narrative is also a fragment of a wider story, that of the Macpherson diaspora. Just as the fragments of rock are conglomerated into one in the cairn, so the personal histories they each embody are fused in the cement of a shared heritage into the collective history of the clan. 
It seems, therefore, that this cairn is not merely a memorial to a Jacobite hero; it is, rather, the clan's memorial to the clan itself: on the one hand, an acknowledgement of its essentially dispersed nature (a clan 'gone on the hill wind'), on the other, an emphatic assertion of the resilience of its attachment to the place it still identifies as home. In a medium as substantial as stone, the monument makes tangible the intangible relationship between a people and its place, and 're-presences', despite its continued absence, the clan in its clan lands. Furthermore, as the place-stories of homeland and diaspora are interfused and articulated within the panorama of the monument, 'Macpherson Country' seems to extend far beyond the bounds of Badenoch to embrace, as we have seen, coalmines in Pennsylvania, goldmines in South Africa, and abandoned sheep stations in Queensland: territories (and identities) delineated not so much by the dithchas of dwelling as by the itineraries of ancestral migrations.

\section{Living in a new (Macpherson) Country}

Another fascinating way in which Macpherson Country may be seen to extend far beyond Badenoch's bounds is in the remarkable number of places named 'Macpherson' (or 'McPherson') throughout the world. As we have already seen in the excerpts from the 'Book of gold', there is a McPherson County in Kansas and a Fort McPherson in Georgia - these are named after the American Civil War hero James 'Birdseye' McPherson, as is McPherson County in South Dakota. There is another Fort McPherson at the head of the Mackenzie River in Canada's North West Territories, this time named after Murdoch McPherson, a factor of the Hudson's Bay Company. To these we may add a further eight McPherson/Macpherson Lakes, two McPherson Points and a Glen McPherson in Canada; a Macpherson's Strait in the Bay of Bengal; another McPherson Point on the coast of Christmas Island; and, in Australia, a Macpherson's Pillar, a McPherson mountain range and no fewer than three Mount Macphersons. ${ }^{43}$

Natural features of the New World landscape were often named in honour of those who funded expeditions during the process of European colonization. Thus, Bill Macpherson, an informant from Western Australia, writes in his family history how his great-grandfather, Donald Macpherson, who emigrated from Badenoch to Western Australia in 1839, had a mountain named after him in acknowledgement of his sponsorship of an expedition led by his land surveyor, F. T. Gregory:

In 1861, Gregory led an expedition through the North West of the State, largely financed by five settlers of whom one was Donald Macpherson. Gregory reached a point about 160 kilometres east of present-day Nullagine before being forced back by lack of food and water. Near that turning point he named Mt Macpherson. Expedition sponsors could expect to get their names on the map, although the records of the Geographic Names Section of the Dept of Land Administration state only that Gregory chose the name of an early settler. One of the family legends had been that a more famous explorer, Sir Lord John Forrest, named Mt Macpherson after Donald. ${ }^{44}$

The expansion of this more literal Macpherson Country in Australia exemplifies the 'rhetorical colonization' of the New World described by the Melbourne-based historian 
Paul Carter, a colonization in which 'the historical space of the white settlers emerged through the medium of language' - and, more precisely, through 'the language of naming. ${ }^{45}$ Through naming, Carter argues, undifferentiated space, itself rhetorically constructed as terra nullius, becomes transformed into an 'object of knowledge': 'something that could be explored and read' and thereby appropriated. ${ }^{46}$ Carter is keen to emphasize that such colonizations should not, however, be understood exclusively as the acts of famous - and not so famous - explorers such as Sir Thomas Mitchell (another Scot, who, incidentally, named the Mount Macpherson on the Darling River in New South Wales), Sir Lord John Forrest, or, indeed, the likes of F. T. Gregory:

To understand the settling process we need to bear in mind that contrary to the imperial paradigm of colonization, in which settlement follows on smoothly from discovery and exploration, the settlers inhabited the new country strategically. They were themselves discoverers and explorers. ${ }^{47}$

Thus Carter cites the example of a $\mathrm{Mr}$ and Mrs Austin, who, in planning the development of a township on their land selection near Geelong, first name it 'Chilwell' after their old home in Derbyshire, England. In the anticipatory act of naming, Carter argues, the Austins create a new place where meanings and associations can accrue. ${ }^{48}$ We may see the same processes at work in the new Macpherson Country: thus we find an Alexander Macpherson naming his property in New South Wales 'Kingussie' after the Badenoch town from which his father emigrated in 1838; or that same Donald Macpherson, namesake of Mount Macpherson in Western Australia, naming his sheep station 'Glentromie' after Glen Tromie in Badenoch (and, indeed, my informant, Bill Macpherson, named his own house 'Glentromie', not after Glen Tromie, Badenoch, but after his great-grandfather's Australian property, thus continuing the toponymic migration).

Carter maintains that the 'spatial histories' these settler-explorer-discoverers were making were orientated towards the future, not invocations of the past. The fact that the Chilwell in Derbyshire which gives its name to the Austin's anticipated township in Victoria has its own etymological roots is not, he suggests, particularly significant. Carter is more concerned with the manner in which the intentional act of naming brings into being a new 'communicable space' and how this constitutes the true 'settling' of a new country. Whilst not disputing the substance of Carter's argument, I believe the significance of these old country names - names such as 'Kingussie' and 'Glentromie', or, for that matter, the township of 'Badenoch' in Ontario - are much more than mere etymological curiosities.

Topographically, whilst the Grampian mountains in Victoria (again named by Mitchell) ${ }^{49}$ may bear some passing resemblance to the Grampian mountains in Scotland, the same could hardly be said of Donald Macpherson's parched 'Glentromie' in Western Australia (Figure 10) and its namesake which cuts through that part of the Grampians which lies in Badenoch. 'When I think of Tromie,' recalls Meta Scarlett, 'I think of picnics far up the glen on luminous summer evenings; of bathing in browndappled pools on lazy afternoons. ${ }^{50}$ It is in the heights of this Glen Tromie that Gaick is to be found, the place where the infamous Black Officer of Ballachroan met his death, 


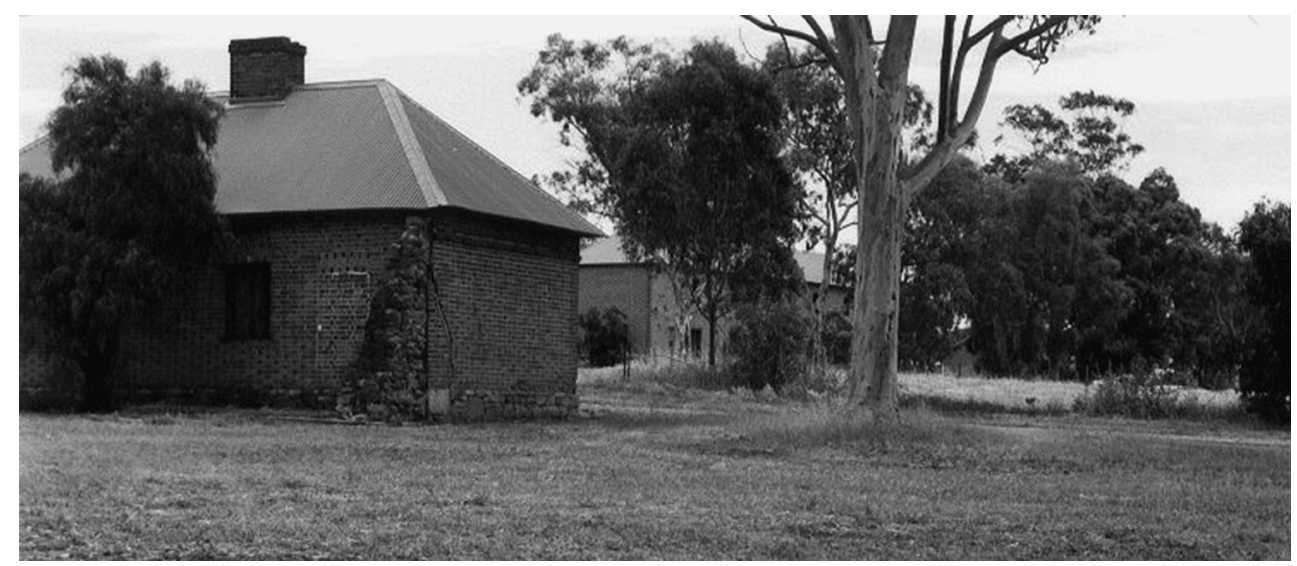

FIGURE 10 'Glentromie' sheep station, Victoria Plains, Western Australia. (Bill Macpherson.)

and it was in this same glen that my informant Bill Macpherson's great-greatgrandfather, 'Old Aeneas', father of Donald, was born in the 1780s. According to Bill's family history, Aeneas married into a family of McIntoshes at a place called Dunachton, across the Spey from Glen Tromie, and it was at Dunachton that Donald himself was born in 1815. As a 24-year old emigrant, Donald was no doubt well acquainted with his father's native glen - its 'dappled pools' as well as its darker associations - and he evidently carried the memory of that place with him to Western Australia. A further 20 years after his emigration, the significance of that memory was still sufficient for Donald, now a successful farmer with a flock of 4000 sheep, 'a fine herd of cattle' and a homestead consisting of 'several substantial buildings', to change the name of his estate from the 'aboriginal' Murra Murra to Glentromie..$^{51}$

Actually, it was the name of his great-grandfather's sheep station in Western Australia, sold after his death, that provoked Bill Macpherson's interest in his family history in the first place and caused him to set off in search of its old country namesake. Thus, in 1989, Bill made a journey to Badenoch, not so much to see the generic Macpherson Country of the clan as to find his own Macphersons' country. He explained to me, 'We didn't know why great-grandpa Donald Macpherson named his Western Australian sheep station Glentromie, and when I eventually did find out, I knew I would have to see the glen.' Of Old Aeneas's four sons, three emigrated to Western Australia, and it was interesting for Bill to discover that his was not the first homecoming in the family. Indeed, the continuing connections between this particular Macpherson diaspora and its homeland were evident in two nineteenth-century gravestones that Bill came across during his visit: the first, now lying broken in Kingussie's Middle Cemetery, was erected in 1853 by Donald's older brother, 'John Macpherson of Western Australia', in memory of their father, Old Aeneas, who had died in 1840; the second, in nearby Alvie churchyard, was dedicated to Duncan and Mary Macpherson, who died at Carnamah in Western Australia in the 1890s. As Bill observes, 
'there must have been someone in Badenoch who remembered them kindly and who had enough money to erect the stone'. 'Or,' he adds, 'did Duncan provide for it out of his own estate?' (suggesting that the old country remained home for him in some profound sense).

Perhaps the most poignant part of Bill's journey to Badenoch, however, was his visit to Dunachton, the farm, originally subdivided into smaller townlands, on which Donald and his brothers had been born and raised in the early nineteenth century (Figure 11). Bill explained,

It is all laid out as shown on the Ordnance Survey maps. I was surprised to find that the little groups of squares and lines on the map are actually the remains of the cottages and enclosure walls of the villages that were there in the time that Old Aeneas raised his children there.

The story of Donald Macpherson and his brothers is, of course, just one among thousands of similar migrant tales; in its specificity, it lends credence to Carter's argument that colonial history must be understood, not as the unfolding of some epic imperial narrative, but in the minutiae of thousands of individual actions and intentions. In naming their new homesteads after old homelands, however, surely these individual colonists were not only making spatial history, as Carter seems to suggest, in the sense of mapping out their futures onto what was, for them, an uncharted and abstract territory; I suggest that they were also historicizing that supposedly 'unhistoried' landscape by importing place names that were already highly charged with memories and associations with the past. May we not conclude that whilst they

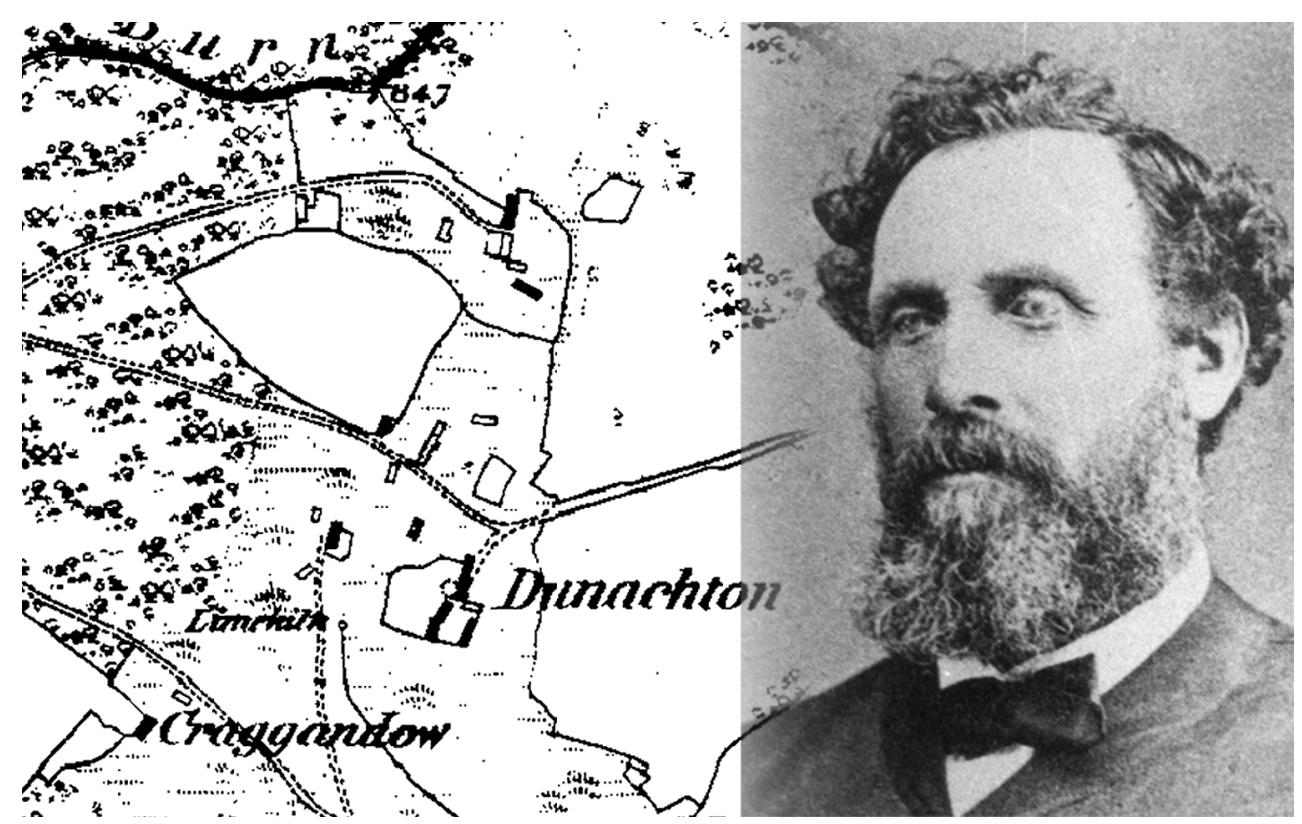

FIGURE 11 Donald Macpherson (1815-87), pictured alongside the 'squares and lines' of Dunachton as represented on the 1st edition Ordnance Survey map. (Bill Macpherson.) 
contemplated new horizons, these colonists were also attempting to make their new country old? And, like the Aboriginal 'dreaming trails' that the settlers knowingly and unknowingly overwrote, may we not perceive in these spatial histories a kind of conduit connecting new lands and place-stories with their ancestral counterparts? Thus, travelling from Macpherson Country to Macpherson Country, Bill is able to reconstruct his genealogy from its linguistic as well as material traces in the landscape and, among the grassed-over ruins of Dunachton, to make sense of the puzzling 'squares and lines' of his maps - to discern in their hieroglyphs a particular meaning of home.

\section{Conclusions}

In an oft-quoted passage, the literary critic Peter Brooks argues:

Our lives are ceaselessly intertwined with narrative, with the stories that we tell and hear told, those we dream or imagine or would like to tell, all of which are reworked in the story of our own lives that we narrate to ourselves in an episodic, sometimes semiconscious, but virtually uninterrupted monologue. ${ }^{52}$

In this paper I have sought to explore this intertwining of personal or autobiographical narratives with those broader cultural and historical narratives we associate with particular regions, nations and diasporas. I have been concerned especially with the intertwining of surnames, place names and 'place-stories', and with notions of clanship, clan lore and clan lands, as resources used in the negotiation of self-identity among members of the transnational Scottish heritage community.

Using the spatial histories and mnemonic practices of the Clan Macpherson as examples, I have attempted to demonstrate how the romantic ideology of Highland clanship serves to re-root members of an 'unsettled' settler society in what is perceived as their ancestral homeland. This (re-)establishment of kinship ties to a particular territory is effected through various enunciative acts: for instance, becoming acquainted with the clan's origin myths, slogans, stories and symbols; visiting the clanlands and those collective 'sites of memory' associated with events in clan history; participating in clan marches and ceremonials; and even researching one's family history - locating one's personal lineage within the broader clan genealogy.

Whilst this sedentary poetics of clanship entails a re-essentialization of identity that has become morally untenable (and empirically dubious) in the contemporary West, I have suggested that, in the context of Scottish diasporic roots-tourism, the assertion of a close bond between blood and soil is more benign. For those who, by virtue of a particular surname or through the labours of their genealogical research, have identified themselves as members of a Scottish Highland diaspora, the ideal of Highland clanship provides a powerful 'answering image' to that represented by the indigenous peoples and cultures of the countries in which their migrant ancestors settled. Sensing their own (vicarious) complicity in the violences of colonization and thus questioning the legitimacy of their 'right to belong' in lands historically appropriated from indigenous populations, the Highland clan provides its diasporic 
members with the possibility of recovering their own indigenous identity and the promise of a return to their own indigenous lands.

For many of my informants the appeal of indigenousness is an appeal to a sense of unproblematic territorial belonging that has become impossible in their diasporic home countries. Through an intertwining of stories told and stories heard, of stories dreamed, imagined and desired, these, the 'morally dispossessed' of the post-colony, are able to participate in a collective 'Celtic dreaming' of their own and, (symbolically) repossessing their Highland homelands, transform the hesitant hope of 'We could belong here' to the confident assertion of 'We $d o$ belong here. ${ }^{53}$

\section{Acknowledgements}

In addition to the many Macphersons, near and far, with whom I shared a dram or two of Dalwhinnie whilst pursuing the research from which this article is drawn, I am especially grateful for the comments and suggestions of Barbara Bender, Philip Crang, Sharon Macdonald, Catherine Nash, Christopher Tilley and three anonymous referees. I also gratefully acknowledge the support of the Economic and Social Research Council, which funded my research.

\section{Notes}

${ }^{1}$ Although not the focus of this article, Sheila's and Colleen's comments also signal the particular gendered dimension of Scottish Highland roots-tourism. Given the ostensible masculinity of clan traditions and commemorative practices, as well as the use of 'totemic' patronyms, it is interesting to note how female roots-tourists understand and adapt clanship as a motif of female ancestral identity. One American informant, for example, described how the act of visiting the homelands of the Clan Matheson on the Isle of Lewis enabled her to recover her female Scottish heritage: "My Scottish heritage had always been a very "male" thing ... the men playing pipes, drinking, telling stories. Visiting Scotland for the first time, I had an overwhelming sense of the women of Scotland... that there had been an unbroken line of women living there, giving birth, raising the clan men, etc. I felt like my heritage was being given back to me, that I had a claim to it as a female.'

2 D. Stasiulis and N. Yuval-Davis, eds, Unsettling settler societies: articulations of gender, race, ethnicity and class (London, Sage, 1995).

3 A. Curthoys, 'Expulsion, exodus and exile in White Australian historical mythology', Journal of Australian studies $6 \mathbf{1}$ (1999), pp. 1-18.

${ }^{4}$ M. Clark, Speaking out of turn: lectures and speeches 1940-1991 (Melbourne, Melbourne University Press, 1997), p. 144.

5 D. Tacey, Reenchantment: the new Australian spirituality (Sydney, HarperCollins, 2000), p. 142 .

${ }^{6}$ For discussions of genealogical heritage-tourism in Irish, Jewish and West African diasporic contexts, see respectively C. Nash, 'Genealogical identities', Environment and planning D: society and space 20 (2002), pp. 27-52; J. Kugelmass, ed., Going home (Eranston, IL, Northwestern University Press, 1993); K. Schramm, 'Coming home to the Motherland: 
pilgrimage tourism in Ghana', in S. Coleman and J. Eade, eds, Reframing pilgrimage: cultures in motion (London, Routledge, 2004), pp. 133-49.

7 P. Gilroy, 'Diaspora and the detours of identity', in K. Woodward, ed., Identity and difference (London, Sage, 1997).

8 S. Hall, 'A place called home: identity and the cultural politics of difference', in J. Rutherford, ed., Identity: community, culture, difference (London, Lawrence \& Wishart, 1990), p. 224.

9 See V. Bell, ed., Performativity and belonging (London, Sage, 1999) for recent discussions on identity and performativity; Anne-Marie Fortier's chapter, 'Re-membering places and the performance of belonging(s)', pp. 41-64, is particularly relevant in the present context. See M. de Certeau, The practice of everyday life (Berkeley, University of California Press, 1984), pp. 97-9, for a discussion of the "'enunciative" function' of walking.

10 Gilroy, 'Diaspora and the detours of identity', p. 310.

11 J. Clifford, Routes: travel and translation in the late twentieth century (Cambridge, MA, Harvard University Press, 1997), p. 7.

12 The particular articulation of landscape, narrative and identity explored in this paper forms part of a wider anthropological study of the relationship between the transnational Scottish heritage community - a diaspora of people who claim Scottish Highland descent dispersed across the USA, Canada, Australia, New Zealand, South Africa and other regions where Scottish migrants have historically settled - and their putative ancestral homeland, the Scottish Highlands and Islands. See P. Basu, 'Homecomings: genealogy, heritage-tourism and identity in the Scottish Highland diaspora' (PhD thesis, University of London, 2002); P. Basu, 'Route metaphors of roots-tourism in the Scottish Highland diaspora', in S. Coleman and J. Eade, eds, Reframing pilgrimage: cultures in motion (London, Routledge, 2004), pp. 150-74; P. Basu, 'Roots-tourism as return movement: semantics and the Scottish diaspora', in M. Harper, ed., Emigrant homecomings (Manchester, Manchester University Press, 2005), pp. 131-50; P. Basu, 'Pilgrims to the far country: North American roots-tourists in the Scottish Highlands and Islands', in C. Ray, Transatlantic Scots (Tuscaloosa, Alabama University Press, forthcoming).

13 M. MacLennan, A pronouncing and etymological dictionary of the Gaelic language (Stornoway, Lewis, Acair, 1979), p. 86.

${ }^{14}$ M. Newton, A handbook of the Scottish Gaelic world (Dublin, Four Courts Press, 2000), pp. $207-11$.

15 R. A. Dodgshon, From chiefs to landlords: social and economic change in the Western Highlands and Islands, c.1493-1820 (Edinburgh, Edinburgh University Press, 1998), p. 3.

16 R. W. Chapman, ed., Johnson's Journey to the Western Islands of Scotland and Boswell's Journal of a tour to the Hebrides with Samuel Johnson (London, Oxford University Press, 1924), p. 42.

17 M. Lynch, Scotland: a new history (London, Pimlico, 1992), p. 69.

18 R. A. Dodgshon, 'Pretense of blude and place of thair duelling: the nature of Scottish clans, 1550-1745', in R. A. Houston and I. D. Whyte, eds, Scottish society, 1500-1800 (Cambridge, Cambridge University Press, 1989), pp. 170-71. The ideological basis of clanship (the 'pretence' of common blood) is, of course, an orthodox anthropological view. As Durkheim writes in 1912, 'the individuals who comprise [a clan] consider themselves joined by a bond of kinship but a bond of a particular sort. This kinship does not arise from the fact that they have well-defined relations of common blood; they are kin solely because they bear the same name. They are not fathers, mothers, sons or daughters, uncles or nephews of one another in the sense we now give those terms; nevertheless they regard themselves as forming a single family ... solely because they are collectively designated by the same word.' E. Durkheim, The elementary forms of religious life (New York, Free Press, 1995), p. 100. Among the 
contemporary Scottish heritage community, the totemic 'object' which collectively designates a group under the same name may be said to be its patronym.

19 C. Ray, Highland heritage: Scottish Americans in the American South (Chapel Hill, University of North Carolina Press, 2001), p. 77; see also my discussion of Don's homecoming in Basu, 'Pilgrims to the far country'.

20 Dodgshon, 'Pretense of blude', p. 174.

21 Newton, Scottish Gaelic world, p. 209.

22 S. Macdonald, 'A people's story: heritage, identity and authority', in C. Rojek and J. Urry, eds, Touring cultures: transformations of travel and theory (London, Routledge, 1997), p. 173; compare with A. B. Weiner, Inalienable possessions: the paradox of keeping-while-giving (Berkeley, University of California Press, 1992).

23 Ray, Highland heritage, p. 128.

24 Ibid., p. 138.

25 A. G. Macpherson, The posterity of the three brethren: a short bistory of the Clan Macpherson (Newtonmore, Inverness-shire, Clan Macpherson Association, 1993), pp. 11-19.

26 Dodgshon, 'Pretense of blude', p. 174; see also A. G. Macpherson, 'An old Highland genealogy and the evolution of a Scottish clan', Scottish studies 10 (1966), pp. 1-42.

27 M. H. Scarlett, In the glens where I was young (Moy, Inverness-shire, Siskin, 1988), p. 124.

28 Ibid., p. 129.

29 R. Clarke ('Rory Mor'), 'In search of the Black Officer', Creag Dhubh 51 (1994), pp. 3035

30 K. H. Basso, 'Wisdom sits in places: notes on a Western Apache landscape', in S. Feld and K. H. Basso, eds, Senses of place (Sante Fe, NM, School of American Research Press, 1996), p. 66.

31 The words are taken from the monument erected at Glenfinnan in 1815 by Alexander MacDonald of Glenaladale, 'to commemorate the generous zeal, the undaunted bravery and the inviolable fidelity of his forefathers and the rest of those who fought and bled' in the Rebellion.

32 Chevalier Johnstone's account, quoted by S. Gordon, Highways and byways in the Central Highlands (Edinburgh, Birlinn, 1995), p. 207.

33 J. Hogg, The Jacobite relics of Scotland (Edinburgh, Blackwood, 1819-21).

34 R. L. Stevenson, Kidnapped (London, Penguin, 1994), pp. 159-66.

35 Gordon, Highways and byways, p. 221.

36 M. Halbwachs, La topographie légendaire des évangiles en Terre Sainte (Paris, Dumont, 1941).

37 P. Connerton, How societies remember (Cambridge, Cambridge University Press, 1989).

38 B. Kapferer, Legends of people, myths of state: violence, intolerance and political culture in Sri Lanka and Australia (Washington, DC, Smithsonian Institution Press, 1988), p. 151.

39 Sandy Macpherson, pers. com.

40 P. Nora, 'Between memory and history: les lieux de mémoire', Representations 26 (1989), pp. 7-25; E. M. Bruner and P. Gorfain, 'Dialogic narration and the paradoxes of Masada', in E. Bruner, ed., Text, play and story: the construction and reconstruction of self and society (Prospect Heights, IL, Waveland, 1988); D. Lowenthal, 'European landscape transformations: the rural residue', in P. Groth and T. W. Bressi, eds, Understanding ordinary landscapes (New Haven, CT, Yale University Press, 1997); P. Basu, 'Sites of memory - sources of identity: landscape-narratives of the Sutherland clearances', in J. Atkinson, I. Banks and G. MacGregor, eds, Townships to farmsteads: rural settlement studies in Scotland, England and Wales (Oxford, BAR British series 293, 2000), pp. 225-36.

41 See C. McArthur, 'Culloden: a pre-emptive strike', Scottish affairs 9 (1994), p. 98. 
42 E. Macpherson, 'Address by Euan Macpherson of Glentruim to the clan on Sunday, 6 August 1995', Creag Dhubb 48 (1996), pp. 7-8.

43 A. G. Macpherson, 'More world-wide Macphersons: the surname as placename', Creag Dbubh 52 (2000), pp. 25-6.

44 R. W. Macpherson, 'The Macphersons and Macknoes in Western Australia' (unpublished family history, [n.d.]), p. 37.

45 P. Carter, The road to Botany Bay: an essay in spatial history (London, Faber \& Faber, 1987), p. 67.

46 Ibid.

47 Ibid., p. 138.

48 Ibid., pp. 137-38.

49 See T. Birch, 'A land so inviting and still without inhabitants: erasing Koori culture from (post-) colonial landscapes', in K. Darien-Smith, L. Gunner and S. Nuttall, eds, Text, theory, space: land, literature and bistory in South Africa and Australia (London, Routledge, 1996), pp. $173-88$.

50 Scarlett, In the glens, p. 73.

51 R. W. Macpherson, 'Macphersons and Macknoes', p. 36.

52 P. Brooks, Reading for the plot: design and intention in narrative (New York, Knopf, 1984), p. 3.

53 See Basu, Homecomings, pp. 190-204, for a more detailed discussion of discourses of 'indigenousness' in Scottish Highland roots-tourism, including the notion of a 'Celtic Dreaming'. 